\title{
ANALISIS PENGARUH PERDAGANGAN INTRA DAN EKSTRA REGIONAL TERHADAP PERTUMBUHAN EKONOMI NEGARA ANGGOTA ASEAN
}

\author{
Desmayani Siregar \\ Rujiman \\ H.B. Tarmizi \\ Fakultas Ekonomi dan Bisnis Universitas Sumatera Utara \\ Email : maya_eeng@yahoo.com
}

\begin{abstract}
The aim of this research is to examine the effect of intra- regional trade in ASEAN, extra regional ASEAN, foreign direct investment, inflation and population to the economic growth of ASEAN member countries. The method of analysis which is used in the research is regression panel with Eviews software 7. The population which is used in this research is ten ASEAN member countries with study period from year 2010 till year 2014. The result showed that, intra- regional trade in ASEAN, extra regional ASEAN, foreign direct investment, inflation and total population simultaneously has a significant effect on the economic growth of ASEAN member countries. Partially, intra-regional ASEAN trade and the number of population have negative effect on the economic growth of ASEAN member countries. While intra- regional trade, foreign direct investment and inflation partially have positive effect on the economic growth on ASEAN member countries.
\end{abstract}

Keywords: Intra-Regional Trade, Extra-Regional Trade ASEAN, Foreign Direct Investment, Inflation, Total Population, and Economy Growth

\section{PENDAHULUAN}

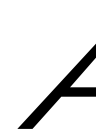
ssosiation of Southeast Asian Nations (ASEAN) dibentuk berdasarkan Deklarasi Bangkok pada tanggal 8 Agustus 1967 yang ditandatangani oleh lima wakil pemerintahan Asia Tenggara yaitu Tun Abdul Razak sebagai Wakil Perdana Menteri merangkap Menteri Luar Negeri Malaysia, Menteri Luar Negeri Adam Malik dari Indonesia, Thanat Koman dari Thailand, Narsisco Ramos dari Filipina dan S. Rajaratman dari Singapura. Pembentukan perhimpunan ini pada hakikatnya merupakan suatu pernyataan politik untuk mengukuhkan kemerdekaan masingmasing negara anggota dari kepentingan super power, sekaligus QE Journal | Vol.07 - N 0.02 July 2018 - 88 
melegitimasi kedaulatan negara-negara anggota dalam upaya mewujudkan stabilisasi di kawasan Asia Tenggara (Sekretariat Nasional ASEAN, Deplu, RI, 2008).

Kerjasama-kerjasama tersebut terealisasi dalam program-program seperti; ASEAN Industrial Project Plan pada tahun 1976, Preferential Trading Arrangement atau ASEAN PTA pada tahun 1977, ASEAN Industrial Complementation Scheme tahun 1981, ASEAN Joint Ventures Scheme tahun 1983 dan Enhanced Preferential Trading Arrangement pada tahun 1987. Hal ini diupayakan oleh negara anggota guna menghadapi tantangan globalisasi yang makin keras (Anabarja, 2010).

Awalnya ASEAN dibentuk untuk memajukan kerjasama di bidang ekonomi, ilmu pengetahuan dan sosial budaya, bidang kerjasama politik dan keamanan belum disebutkan di dalam Deklarasi ASEAN tersebut. Kerjasama politik dan keamanan baru dimulai dalam pertemuan para Menteri Luar Negeri di Kuala Lumpur pada tanggal 27 November 1971, dengan Deklarasi Kuala Lumpur yang disebut Deklarasi ZOPFAN (Zone of Peace, Freedom and Naturality Declaration). Oleh karena itu, ASEAN mempunyai peranan penting dalam menyelesaikan krisis-krisis yang terjadi di dalam kawasan (ASEAN Sekretariat, 1998).

Pada akhir dekade 1990-an terjadi perubahan lingkungan strategis global yang menuntut negara-negara di dunia melakukan peningkatan daya saingnya. Globalisasi membuka nuansa baru dalam hubungan ekonomi antarnegara di seluruh dunia. Kondisi ini memungkinkan terbukanya pasar ekonomi secara luas tanpa adanya hambatan geografis dan teritorial (Saleh, 2010). Globalisasi diindikasikan dengan berkembangnya arus modal, percepatan alih teknologi dan perkembangan telekomunikasi lintas batas negara terutama dalam bidang ekonomi dan perdagangan.

Dengan adanya kerjasama regional, negara-negara yang tergabung dalam anggotanya tersebut terdorong untuk meminimalisasi atau menghapuskan hambatan perdagangan dengan anggota kerjasama kawasan tersebut. Dengan demikian, adanya kerjasama regional yang pada awalnya implikasinya bersifat hanya dalam kawasan tersebut, pengaruhnya juga dapat dirasakan secara mengglobal. Dalam hal ini, ASEAN yang bekerjasama dengan banyak negara akhirnya dapat memperluas pasarnya 
hingga ke negara-negara kawasan lain meskipun banyak hambatanhambatan yang ditemui dalam prosesnya (Winarno, 2011).

ASEAN Free Trade Area (AFTA) merupakan salah satu bentuk perjanjian kerjasama di bidang ekonomi yang disepakati oleh seluruh negara anggota ASEAN tahun 1992. AFTA merupakan wujud kesepakatan dari negaranegara ASEAN untuk membentuk suatu kawasan perdagangan bebas dalam rangka meningkatkan daya saing ekonomi kawasan regional ASEAN, dengan menciptakan pasar regional bagi penduduknya dan menjadikan ASEAN sebagai basis produksi dunia, sehingga dapat menarik investasi dan meningkatkan perdagangan antarnegara anggota ASEAN, melalui skema Common Effective Preferential Tariffs (CEPT). Dalam skema CEPT, tarif yang dikenakan oleh setiap negara anggota ASEAN terhadap barang-barang impor dari negara ASEAN lainnya harus dikurangi tidak lebih dari 5\% (Deperindag, 2002).

Dengan adanya AFTA, maka peluang kerjasama ekonomi tersebut sangat berpotensi untuk meningkatkan nilai trade openness atau ekspor dan impor masing-masing negara di ASEAN. Sehingga dengan meningkatnya ekspor dan impor tersebut maka akan meningkatkan cadangan devisanya yang akan menggerakkan perekonomian dan pertumbuhan ekonomi di negaranegara kawasan tersebut.

Selain itu, telah dirintis pula kerangka kerjasama untuk mewujudkan Masyarakat Ekonomi ASEAN (ASEAN Economic Community, AEC) pada tahun 2015 dan Masyarakat Ekonomi Asia Timur (East Asian Economic Community, EAEC) yang dipelopori oleh negara-negara ASEAN, China, Jepang dan Korea Selatan atau dikenal dengan sebutan ASEAN+3. Kerjasama regional ASEAN+3 dimaksudkan untuk menjadikan kawasan ini sebagai kutub baru pertumbuhan dunia, selain European Union (EU) di Benua Eropa dan North American Free Trade Area (NAFTA) di Kawasan Amerika Utara (Purwanto, 2011).

Berikut akan disajikan perkembangan perdagangan intra-regional dan perdagangan ekstra-regional yang dilakukan negara-negara anggota ASEAN dari tahun 2010 sampai dengan 2014.

Adapun tujuan dilakukannya kerjasama ekonomi di bidang perdagangan baik perdagangan intra maupun ekstra-regional adalah untuk meningkatkan pemerataan kesejahteraan masing-masing negara anggota

$$
\text { Q E J ournal | Vol.07 - N o. } 02 \text { July } 2018 \text { - } 90
$$


ASEAN. Kesejahteraan ini diukur melalui pencapaian pertumbuhan ekonomi yang tinggi sebagai dampak positif dari hubungan kerjasama regional di kawasan Asia Tenggara. Semakin tinggi nilai perdagangan yang dilakukan maka diharapkan pertumbuhan ekonomi masing-masing negara anggota ASEAN juga berpotensi menjadi lebih baik.

Tabel 1.1 Perkembangan Perdagangan Intra dan Ekstra-Regional Negara Anggota ASEAN Tahun 2010-2014 (US\$ Juta)

\begin{tabular}{|c|c|c|c|c|c|}
\hline \multirow{2}{*}{ Negara } & \multicolumn{5}{|c|}{ Tahun } \\
\hline & 2010 & 2011 & 2012 & 2013 & 2014 \\
\hline \multicolumn{6}{|l|}{ Intra-ASEAN } \\
\hline Brunei Darussalam & $2,267.6$ & $2,912.1$ & $3,340.1$ & $4,488.0$ & $3,860.7$ \\
\hline Cambodia & $2,384.6$ & $3,003.8$ & $5,142.9$ & $4,119.1$ & $7,615.5$ \\
\hline Indonesia & $80,472.6$ & $99,353.2$ & $95,654.5$ & $94,661.8$ & $90,725.3$ \\
\hline Lao PDR & $2,576.5$ & $2,530.3$ & $2,337.2$ & $3,729.3$ & $3,496.3$ \\
\hline Malaysia & $95,270.6$ & $108,217.9$ & $115,812.7$ & $119,032.2$ & $118,965.0$ \\
\hline Myanmar & $5,733.1$ & $7,207.7$ & $7,525.4$ & $9,869.0$ & $11,455.0$ \\
\hline Phillipines & $27,827.5$ & $23,675.6$ & $24,758.3$ & $22,786.2$ & $25,370.0$ \\
\hline Singapore & $181,198.4$ & $205,673.7$ & $209,621.3$ & $206,672.3$ & $203,196.4$ \\
\hline Thailand & $86,610.7$ & $111,450.8$ & $99,535.5$ & $103,668.6$ & $102,725.3$ \\
\hline Viet Nam & $26,678.3$ & $34,298.1$ & $38,320.2$ & $39,531.9$ & $40,797.7$ \\
\hline Total & $511,019.9$ & $598,323.2$ & $602,048.1$ & $608,558.4$ & $608,207.2$ \\
\hline \multicolumn{6}{|l|}{ Ekstra-ASEAN } \\
\hline Brunei Darussalam & $8,731.5$ & $11,910.2$ & $13,516.2$ & $10,569.2$ & $10,320.1$ \\
\hline Cambodia & $8,095.8$ & $9,840.3$ & $13,520.8$ & $14,205.0$ & $22,039.1$ \\
\hline Indonesia & $212,969.7$ & $281,579.1$ & $286,066.8$ & $274,518.7$ & $263,746.2$ \\
\hline Lao PDR & $1,932.6$ & $1,425.5$ & $3,821.6$ & $2,155.6$ & $1,892.5$ \\
\hline Malaysia & $268,263.7$ & $307,287.2$ & $308,117.6$ & $315,196.5$ & $323,812.9$ \\
\hline Myanmar & $6,065.2$ & $7,717.4$ & $10,977.9$ & $13,756.5$ & $15,801.8$ \\
\hline Phillipines & $81,832.9$ & $88,076.0$ & $92,623.3$ & $96,322.7$ & $104,196.9$ \\
\hline Singapore & $481,459.8$ & $569,493.4$ & $578,495.6$ & $576,593.2$ & $572,819.6$ \\
\hline Thailand & $298,430.1$ & $347,453.5$ & $377,766.4$ & $374,578.7$ & $352,800.6$ \\
\hline Viet Nam & $130,314.8$ & $165,284.0$ & $189,473.1$ & $225,242.1$ & $252,979.4$ \\
\hline Total & $1,498,096.1$ & $1,790,066.6$ & $1,874,379.3$ & $1,903,138.2$ & $1,920,409.1$ \\
\hline
\end{tabular}

Sumber: ASEAN Statistical Year Book 2015

QE Journal |Vol.07 - No. 02 July 2018 - 91 
Berdasarkan rumusan masalah diatas, maka tujuan penelitian ini adalah :

1. Untuk menganalisis pengaruh perdagangan intra-regional ASEAN terhadap pertumbuhan ekonomi negara anggota ASEAN.

2. Untuk menganalisis pengaruh perdagangan ekstra-regional ASEAN terhadap pertumbuhan ekonomi negara anggota ASEAN.

3. Untuk menganalisis pengaruh investasi asing langsung terhadap pertumbuhan ekonomi negara anggota ASEAN.

4. Untuk menganalisis pengaruh inflasi terhadap pertumbuhan ekonomi negara anggota ASEAN.

5. Untuk menganalisis pengaruh jumlah penduduk terhadap pertumbuhan ekonomi negara anggota ASEAN.

6. Untuk menganalisis pengaruh perdagangan intra-regional, ekstraregional, investasi asing langsung, inflasi dan jumlah penduduk secara simultan terhadap pertumbuhan ekonomi negara anggota ASEAN.

Dalam landasan teori, akan dibahas lebih lanjut mengenai teori-teori yang mempengaruhi pertumbuhan ekonomi di kawasan Asia Tenggara sebagai dampak adanya perdagangan regional antarnegara ASEAN. Adapun teori yang akan diuraikan yaitu mengenai pertumbuhan ekonomi, perdagangan internasional, investasi asing, inflasi dan pertumbuhan penduduk.

Pertumbuhan ekonomi adalah proses kenaikan output per kapita dalam jangka panjang. Pengertian tersebut mencakup tiga aspek, yaitu proses, output per kapita dan jangka panjang. Pertumbuhan ekonomi merupakan suatu proses, bukan gambaran ekonomi pada suatu saat. Mencerminkan aspek dinamis dari suatu perekonomian, yaitu melihat bagaimana suatu perekonomian berkembang atau berubah dan waktu ke waktu. Pertumbuhan ekonomi berkaitan dengan kenaikan output per kapita (Boediono, 1999). Aspek lain dari definisi pertumbuhan ekonomi adalah perspektif waktu jangka waktu suatu perekonomian dikatakan mengalami pertumbuhan apabila dalam waktu yang cukup lama (10, 20 atau 50 tahun atau bahkan lebih lama lagi) mengalami kenaikan output per kapita.

Kerangka konseptual merupakan skema/kerangka sederhana untuk memberikan gambaran mengenai penelitian yang akan dilakukan secara keseluruhan agar dapat diketahui secara jelas dan terarah. Dalam penelitian ini akan dianalisa bagaimana pengaruh perdagangan intra- 
regional, perdagangan ekstra-regional ASEAN, investasi asing, inflasi dan pertumbuhan penduduk secara parsial dan simultan terhadap pertumbuhan ekonomi negara anggota ASEAN selama periode tahun 2010 sampai dengan tahun 2014.

\section{METODE PENELITIAN}

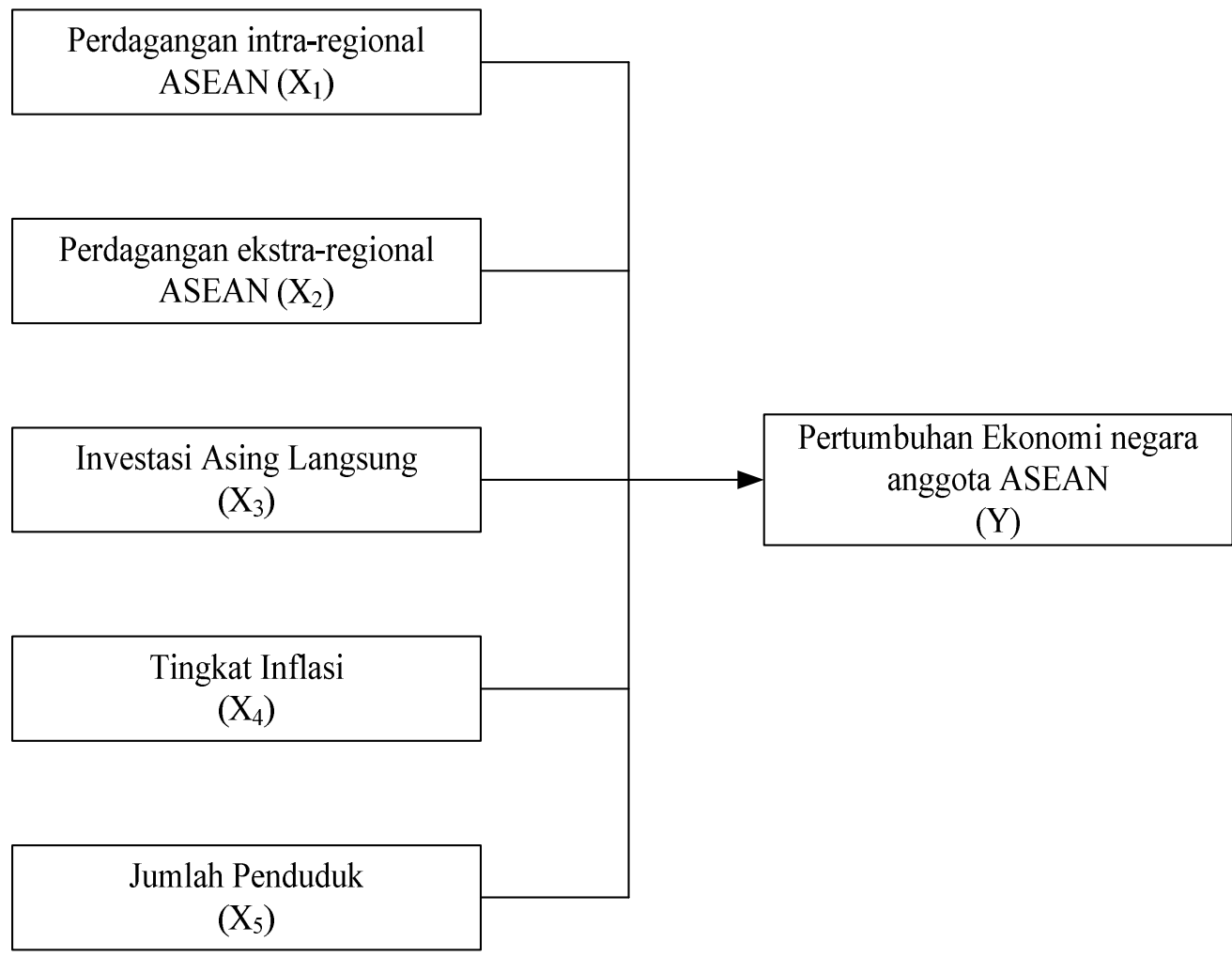

Gambar 1 Kerangka Konseptual

Ruang lingkup penelitian ini adalah untuk menganalisis pengaruh perdagangan intra-regional, perdagangan ekstra-regional, investasi asing langsung, inflasi dan pertumbuhan penduduk terhadap pertumbuhan ekonomi negara anggota ASEAN. Penelitian ini dilakukan pada sepuluh negara yang menjadi anggota ASEAN. Penelitian ini dilaksanakan dengan memusatkan pembahasan mengenai pengaruh perdagangan intra-regional, perdagangan ekstra-regional, investasi asing langsung, inflasi dan pertumbuhan penduduk terhadap pertumbuhan ekonomi negara anggota ASEAN dalam periode penelitian tahun 2010 sampai dengan tahun 2014. Waktu penelitian direncanakan akan dimulai dari bulan Mei 2017. Dalam

$$
\text { QE Journal | Vol.07 - N o. } 02 \text { July } 2018 \text { - } 93
$$


penelitian ini terdapat lima variabel eksogenus yaitu perdagangan intraregional, perdagangan ekstra-regional, investasi asing langsung, inflasi dan jumlah penduduk sepuluh negara anggota ASEAN serta satu variabel endogenus yaitu terhadap pertumbuhan ekonomi sepuluh negara anggota ASEAN.

Penelitian ini menggunakan data sekunder. Data sekunder yaitu berupa dokumentasi dengan pengumpulan bahan-bahan dan data yang berhubungan dengan pokok bahasan yang peneliti kutip dari buku dan jurnal atau laporan historis yang telah disusun dalam arsip yang berasal dari situs website organisasi ASEAN mengenai Laporan Statistik Tahunan ASEAN. Adapun jenis data yang dipergunakan dalam penelitian ini adalah data sekunder tahunan, yang merupakan data time series dan cross section (data panel) dengan rentang waktu dari tahun 2010 sampai dengan tahun 2014 dan diolah menggunakan software Eviews 7.

Penelitian ini akan menguji faktor-faktor yang berpengaruh terhadap pertumbuhan ekonomi negara-negara anggota ASEAN dalam kurun waktu lima tahun. Dengan demikian, metode penelitian ini akan menggunakan metode pengujian data panel. Dengan demikian, model analisis yang akan digunakan pada penelitian ini adalah:

$$
P E_{i}=\beta_{0}+\beta_{1} I T_{i}+\beta_{2} E T_{i}+\beta_{3} I V_{i}+\beta_{4} \operatorname{Inf}_{i}+\beta_{5} J P_{i}+\varepsilon
$$

dimana:

$\mathrm{PE}_{\mathrm{i}}=$ pertumbuhan ekonomi negara $\mathrm{i}(\%)$

$\mathrm{IT}_{\mathrm{i}}=$ perdagangan intra-regional negara $\mathrm{i}$ tahun $\mathrm{t}(\mathrm{US} \$)$

$\mathrm{ET}_{\mathrm{i}} \quad=$ perdagangan ekstra-regional negara i pada tahun $\mathrm{t}(\mathrm{US} \$)$

$\mathrm{IV}_{\mathrm{i}}=$ nilai investasi langsung negara i pada tahun $\mathrm{t}$ (US\$)

Inf $_{\mathrm{i}}=$ tingkat inflasi di negara $\mathrm{i}$ pada tahun $\mathrm{t}(\%)$

$\mathrm{JP}_{\mathrm{i}} \quad=$ jumlah penduduk di negara i pada tahun $\mathrm{t}$ (orang)

$\beta_{0}=$ konstanta

$\beta_{1}, . ., \beta_{5}=$ parameter untuk perubahan pengaruh variable eksogen terhadap variabel endogen

i = negara-negara anggota ASEAN

$\varepsilon \quad=$ error term

\section{HASIL DAN PEMBAHASAN}

Dari hasil uji kesesuaian model diketahui bahwa model yang sesuai dengan analisa penelitian ini adalah Fixed Effect Model (FEM), dengan Q E J ournal | Vol.07 - N o. 02 July 2018 - 94 
demikian, persamaan dari fungsi pertumbuhan ekonomi negara-negara anggota ASEAN adalah sebagai berikut:

1. Persamaan dari fungsi pertumbuhan ekonomi Brunei Darussalam PE_BD $=1.19616-2.666020^{*} \mathrm{IT} \_\mathrm{BD}+0.172398^{*} \mathrm{ET} \_\mathrm{BD}+0.158943^{*} \mathrm{IV} \_\mathrm{BD}+$ 0.099685*Inf_BD $-0.083966 *$ JP_BD

2. Persamaan dari fungsi pertumbuhan ekonomi Kamboja PE_KBJ $=7.64917-2.666020^{*} \mathrm{IT} \_$KBJ $+0.172398^{*} \mathrm{ET}$ _KBJ + $0.158943^{*} \mathrm{IV} \_K B J+0.099685^{*}$ Inf_KBJ $-0.083966^{*} \mathrm{JP} \_K B J$

3. Persamaan dari fungsi pertumbuhan ekonomi Indonesia PE_IDN $=27.24464-2.666020^{*}$ IT_IDN $+0.172398^{*}$ ET_IDN + $0.158943 * I V \_I D N+0.099685^{*}$ Inf_IDN - 0.083966*JP_IDN

4. Persamaan dari fungsi pertumbuhan ekonomi Laos PE_LS $=8.14841-2.666020^{*}$ IT_LS + 0.172398*ET_LS + 0.158943*IV_LS + 0.099685*Inf_LS - 0.083966*JP_LS

5. Persamaan dari fungsi pertumbuhan ekonomi Malaysia PE_MLY $=30.1787-2.666020^{*}$ IT_MLY + 0.172398*ET_MLY + $0.158943^{*}$ IV_MLY + 0.099685*Inf_MLY - 0.083966*JP_MLY

6. Persamaan dari fungsi pertumbuhan ekonomi Myanmar PE_MYM $=9.992008-2.666020^{*}$ IT_MYM + 0.172398*ET_MYM + 0.158943*IV_MYM + 0.099685*Inf_MYM - 0.083966*JP_MYM

7. Persamaan dari fungsi pertumbuhan ekonomi Philipina PE_PHP $=11.692532-2.666020 * I T \_P H P+0.172398^{*} E T \_P H P+$ 0.158943*IV_PHP + 0.099685*Inf_PHP - 0.083966*JP_PHP

8. Persamaan dari fungsi pertumbuhan ekonomi Singapura PE_SGP $=50.33997-2.666020^{*}$ IT_SGP $+0.172398^{*}$ ET_SGP + $0.158943 *$ IV_SGP $+0.099685^{*}$ Inf_SGP $-0.083966^{*}$ JP_SGP

9. Persamaan dari fungsi pertumbuhan ekonomi Thailand PE_THL $=24.924051-2.666020^{*} \mathrm{IT}_{-} \mathrm{THL}+0.172398^{*} \mathrm{ET}_{-} \mathrm{THL}+$ $0.158943^{*} \mathrm{IV}_{-} \mathrm{THL}+0.099685^{*}$ Inf_THL $-0.083966^{*} \mathrm{JP}$ _THL

10. Persamaan dari fungsi pertumbuhan ekonomi Vietnam PE_VTN $=11.880567-2.666020^{*}$ IT_VTN $_{-}+0.172398^{*}{ }^{*}$ TTVTN $_{-}+$ $0.158943 *$ IV_VTN $+0.099685^{*}$ Inf_VTN $-0.083966^{*} J P$ VTTN

Selanjutnya dilakukan pengujian terhadap pertumbuhan ekonomi masingmasing negara anggota ASEAN. Hasilnya dapat dilihat pada tabel berikut. 
Tabel 1. Hasil Regresi Pertumbuhan Ekonomi ASEAN

Dependent Variable: Pertumbuhan Ekonomi

Method: Pooled Least Squares

Sample: 20102014

Included observations: 5

Cross-sections included: 10

Total pool (balanced) observations: 50

\begin{tabular}{lcccc}
\hline \multicolumn{1}{c}{ Variable } & Coefficient & Std. Error & t-Statistic & Prob. \\
\hline C & 18.32462 & 0.193508 & 1.535359 & 0.1337 \\
IntraASEAN & -2.666020 & 0.860640 & -3.097717 & 0.0038 \\
EkstraASEAN & 0.172398 & 0.043599 & 0.707712 & 0.0038 \\
Investasi & 0.158943 & 0.042342 & 0.054019 & 0.0172 \\
Inflasi & 0.099685 & 0.038583 & 0.719319 & 0.0367 \\
JumlahPenduduk & -0.083966 & 0.009256 & -0.040383 & 0.0480 \\
Fixed Effects (Cross) & & & & \\
_BRUNEIDARUSSALAM--C & -17.12846 & & & \\
_CAMBODIA--C & -10.67545 & & & \\
_INDONESIA--C & 8.920020 & & & \\
_LAOPDR--C & -10.17621 & & & \\
_MALAYSIA--C & 11.85408 & & & \\
_MYANMAR--C & -8.332612 & & & \\
_PHILLIPINES--C & -6.632088 & & & \\
_SINGAPORE--C & 32.01535 & & & \\
_THAILAND--C & 6.599431 & & & \\
_VIETNAM--C & -6.444053 & & & \\
\hline
\end{tabular}

Cross-section fixed (dummy variables)

Effects Specification

R-squared

0.710147

Mean dependent var

5.750000

Adjusted R-squared

0.594205

S.D. dependent var

2.908204

S.E. of regression

1.852585

Akaike info criterion

4.314366

Sum squared resid

120.1225

Schwarz criterion

4.887973

Log likelihood

$-92.85916$

Hannan-Quinn criter.

4.532799

F-statistic

6.125049

Durbin-Watson stat

1.900835

Prob(F-statistic)

0.000007

Sumber: Hasil Olahan dengan Eviews 7

Dari fungsi persamaan tersebut dapat dilihat konstanta atau intersep masing-masing negara anggota ASEAN bervariasi. Singapura mempunyai

QE Journal |Vol.07 - No. 02 July 2018 - 96 
konstanta terbesar dibandingkan sembilan negara anggota ASEAN lainnya yaitu sebesar 50.33997, kemudian diikuti oleh Malaysia sebesar 30.1787, Indonesia sebesar 27.24464 dan Thailand sebesar 24.924051. Dari hasil penelitian ini, maka dapat dibentuk persamaan untuk pertumbuhan ekonomi sebagai berikut:

$$
\begin{aligned}
& P E_{i}=\beta_{0}+\beta_{1} I T_{i}+\beta_{2} E_{i}+\beta_{3} I V_{i}+\beta_{4} \operatorname{Inf}_{i}+\beta_{5} \mathrm{IP}_{i}+\varepsilon \\
& \mathrm{PE}_{i}=18.32462-2.666020 \mathrm{IT}_{\mathrm{i}}+0.172398 \mathrm{ET}_{\mathrm{i}}+0.158943 \mathrm{IV}_{\mathrm{i}}+ \\
& \text { 0.099685Infi }-0.083966 \mathrm{JP}_{\mathrm{i}} \\
& \mathrm{t} \text {-sig }=\left(\begin{array}{lllll}
0.1337) & (0.0038) & (0.0038) & (0.0172) & (0.0367)
\end{array}\right. \\
& (0.0480)
\end{aligned}
$$

Adapun interpretasi hasilnya yaitu:

a. Koefisien $I T=-2.666020$ dan $t$-sig $=0.0038$

Berdasarkan hasil persamaan struktural diketahui variabel perdagangan intra-regional negara anggota ASEAN berpengaruh negatif terhadap pertumbuhan ekonomi negara anggota ASEAN.

b. Koefisien $E T=0.172398$ dan $t$-sig $=0.0038$

Berdasarkan hasil persamaan struktural diketahui variabel perdagangan ekstra-regional negara anggota ASEAN berpengaruh positif terhadap pertumbuhan ekonomi negara anggota ASEAN.

c. Koefisien $I V=0.158943$ dan $t$-sig $=0.0172$

Berdasarkan hasil persamaan struktural diketahui variabel investasi berpengaruh positif terhadap pertumbuhan ekonomi negara anggota ASEAN.

d. Koefisien INF $=0.099685$ dan $t$-sig $=0.0367$

Berdasarkan hasil persamaan struktural diketahui variabel inflasi berpengaruh positif terhadap pertumbuhan ekonomi negara anggota ASEAN.

e. Koefisien JP $=-0.083966$ dan $t$-sig $=0.0480$

Berdasarkan hasil persamaan struktural diketahui variabel jumlah penduduk berpengaruh negatif terhadap pertumbuhan ekonomi negara anggota ASEAN. 


\section{SIMPULAN DAN SARAN}

Berdasarkan hasil analisis data yang telah diuraikan pada bab sebelumnya, maka dapat diambil kesimpulan mengenai pengaruh perdagangan intraregional ASEAN, perdagangan ekstra-regional ASEAN, investasi asing langsung, inflasi dan jumlah penduduk terhadap pertumbuhan ekonomi negara anggota ASEAN sebagai berikut:

1. Perdagangan intra-regional ASEAN berpengaruh negatif terhadap pertumbuhan ekonomi negara anggota ASEAN.

2. Perdagangan ekstra-regional ASEAN berpengaruh positif terhadap pertumbuhan ekonomi negara anggota ASEAN.

3. Investasi asing langsung berpengaruh positif terhadap pertumbuhan ekonomi negara anggota ASEAN.

4. Inflasi berpengaruh positif terhadap pertumbuhan ekonomi negara anggota ASEAN.

5. Jumlah penduduk berpengaruh negatif terhadap pertumbuhan ekonomi negara anggota ASEAN.

6. Perdagangan intra-regional, ekstra-regional, investasi asing langsung, inflasi dan jumlah penduduk secara simultan berpengaruh signifikan terhadap pertumbuhan ekonomi negara anggota ASEAN.

\section{DAFTAR PUSTAKA}

Anabarja, Sarah. 2010. Kendala dan Tantangan Indonesia dalam Mengimplementasikan ASEAN Free Trade Area Menuju Terbentuknya ASEAN Economic Community. Universitas Pembangunan Nasional "Veteran": Jawa Timur.

ASEAN Secretariat. 1998. Handbook on Selected ASEAN Political Documents.

Boediono. 1999. Teori Pertumbuhan Ekonomi. BPFE UGM: Yogyakarta.

Purwanto, Tri. 2011. Dampak Keterbukaan Perdagangan terhadap Pertumbuhan Ekonomi di Negara-negara ASEAN+3. Tesis. IPB: Bogor.

Saleh, Samsubar dan Bambang Suprayitno, 2010. ASEAN Economic Integration: Trade Creation or Trade Diversion for Import of Indonesia Manufactures?. Economic Journal of Emerging Markets.

Winarno, Budi. 2011. Isu-Isu Global Kontemporer. CAPS: Jakarta.

$$
\text { QE Journal | Vol.07 - N o. } 02 \text { July } 2018 \text { - } 98
$$

